\title{
Effects of Paprika Extract and Its Components on Cell Death and Expression of p53 and GADD45 Genes in Ultraviolet B- Exposed HaCaT Cells
}

\author{
Se Eun Ha, Hyung-Do Kim, Jea Ran Kang and Jong Kun Park* \\ Division of Biological Science and Research Institute for Basic Science, Wonkwang University, Iksan, Jeonbuk 570-749, Korea
}

Received 3.17, 2011 /Accepted 5.19, 2011

\begin{abstract}
In the present study, the effects of paprika extract and its components including vitamin $C$, lycopene and beta-carotene on cell death in ultraviolet $\mathrm{B}$ (UVB)-exposed HaCaT cells were investigated. The cell viability upon treatment for $24 \mathrm{hr}$ with either paprika extract or vitamin $\mathrm{C}$ alone was similar to or greater than that of the untreated control. However, the viability of the cells treated with lycopene or beta-carotene decreased to about $20 \%$ of that in the untreated control. When UVB-exposed cells were post-incubated for $24 \mathrm{hr}$ in medium containing paprika extract or vitamin C, cell viability increased in a concentration dependent manner as compared to those post-incubated in a normal growth medium. In contrast, post-incubation of UVB-exposed cells with lycopene or beta-carotene decreased cell viability in a concentration dependent manner as compared to those post-incubated in a normal growth medium. The nuclear fragmentation analysis showed that paprika extract or vitamin $\mathrm{C}$ decreases UVB-induced apoptosis. The apoptotic nuclear fragmentation resulting from UVB exposure was also protected by the paprika extract or vitamin C post-incubation. However, the UVB-induced apoptotic nuclear fragmentation of the cells treated with lycopene or beta-carotene increased in a concentration dependent manner. Western blot analysis showed that either paprika extract or vitamin $C$ treatment alone did not significantly change the level of p53 and GADD45 protein. Interestingly, post-incubation of UVB-exposed cells with paprika extract or vitamin $C$ decreased the p53 and GADD45 protein level as compared to those post-incubated in a normal growth medium. In contrast, incubation of UVB-exposed or non-irradiated cells with lycopene or beta-carotene increased the p53 and GADD45 protein levels in a concentration dependent manner as compared to those incubated in a normal growth medium. All these results suggest that paprika extract and vitamin $\mathrm{C}$ help the survival of the UVB-exposed cells, while lycopene and beta-carotene potentiate the apoptotic death of UVB-exposed cells, in accordance with the respective changes in p53 and GADD45 protein levels.
\end{abstract}

Key words : Paprika, lycopene, beta-carotene, vitamin C, UVB-induced cell death

\section{서 론}

자외선은 인체 피부에서 비타민 D 생성과 같은 유익한 작용 을 하는 반면 과도한 자외선 조사는 IL-6, IL-8, IL-10과 같은 다양한 염증매개 사이토카인들을 발현시켜 직간접적으로 피 부의 염증반응에 관여하고 있다[1,12,15,22]. 자외선 B는 자외 선 중 세포자멸사 과정을 유도하는 주요 파장대로, 피부의 각 질세포에 과도한 자외선이 조사되면 먼저 활성산소가 과다하 게 생성되어 항산화 인자로 조절할 수 있는 한계를 넘게 되면 단백질, DNA 그리고 지질의 산화 과정이 유도되어 세포에 유해한 영향을 끼쳐 결국 자외선B 매개성 세포자멸사 과정을 유도한다[10].

자외선에 의해 유도되는 세포고사의 특징은 핵의 분절, 세 포의 수축, 단백질 붕괴, 염색질 응축 그리고 $\mathrm{DNA}$ 분절과 같

\footnotetext{
*Corresponding author

Tel : +82-63-850-6200, Fax : +82-63-843-2781

E-mail : jkpark@wonkwang.ac.kr
}

은 특징을 보인다. 세포고사는 p53 의존성 경로와 Fas/FasL 등이 관여하는 p53 비의존성 경로가 모두 가능함이 보고되어 있다[8]. p53 단백질은 17 번 염색체의 단완에 위치하는 p53 유전자에 의해 생성되는 $53 \mathrm{KDa}$ 크기의 인 단백질로서 세포 핵에 존재 하는데 wild type의 p53은 DNA에 결합하여 세포주 기 중 G1-S phase check point로 작용하여 G1기에서 arrest를 유도하여 세포고사가 일어나도록 하여 세포증식을 억제하는 암 억제 유전자로 알려져 있다[8,12,23]. p53에 의해서 활성화 되는 유전자의 산물 중 $\mathrm{MDM} 2$ 는 $\mathrm{p} 53$ 에 결합하여 $\mathrm{p} 53$ 의 활성 화 domain을 가려 줌으로서 전사 활성을 억제하여 암으로 진 행시킨다. 또한, MDM2 유전자의 첫 번째 intron의 cryptic promoter에는 2개의 p53 결합 motif가 있는데, 세포 내에서 p53이 유도될 때 이 promoter가 작동하여 MDM2 mRNA가 축적 된다. 따라서 $\mathrm{p} 53$ 과 $\mathrm{MDM} 2$ 간의 상호작용은 자가조절 loop을 진행하고 이것은 생리적인 조건하에서 $\mathrm{p} 53$ 활성의 정 도와 시간을 유지시키는데 작용한다[7,11]. 또 다른 p53의 표 적유전자 산물인 p21은 세포주기를 진행하는 cyclin-depend- 
ent kinases (cdk)의 저해제로 작용하여 DNA 복제와 세포분 열을 방해하며, PCNA와 작용하여 DNA 복제를 억제한다. 전 리 방사선 등의 DNA 상해요인은 p53을 활성화시켜 $\mathrm{p} 21$, $\mathrm{MDM} 2$ 그리고 GADD45 등의 downstream effector 유전자를 활성화시킨다. 방사선에 의해 유도된 G1 정지는 malanoma 세포에서 GADD45의 유도가 안되고 p53-p21 경로에 의해서 일어날 것으로 생각된다. GADD45가 유도된 melanoma 세포 에서 p21 mRNA의 계속된 발현의 유도는 없으나, 결손 $\mathrm{GADD} 45$ 를 유도한 세포에서 $\mathrm{p} 21$ 을 상보하고, 자외선 상해에 대해서도 $\mathrm{p} 53$ 은 $\mathrm{GADD} 45$ 을 통해 $\mathrm{DNA}$ 회복과 연관됨이 알려 졌다[20,25,30].

파프리카는 가지과에 속하는 한해살이 식물로 6 개의 아종 이 있다. 현재까지 파프리카는 항산화 작용을 나타내는 여러 가지 성분들의 분리에 관한 연구가 활발히 진행되고 있으며, 화학적인 암 예방 활성에 대한 연구가 보고되었다. $\mathrm{Yu}$ 등 (2006)은 암예방 효소로 알려진 quinine reductase 활성의 유 도에 효능이 있는 것으로 보고하였다[37]. 파프리카는 capsanthine, b-cryptoxanthine, zeaxanthine 등의 카로티노이드 계 색소를 함유하고 있으며 비타민 $\mathrm{A}, \mathrm{B}$ 및 C가 풍부하다고 알려져 있다[4,9].

파프리카의 주된 성분 중 하나인 비타민 C는 대표적인 항산 화제로 세포에 독성을 나타내지 않고 암 예방 효과를 주는 영양소로 인체 내에서 생성되는 자유 라디칼의 위험을 감소시 키며 항산화력을 가지고 있다[35]. In vitro 상에서 대부분의 플라보노이드가 산화현상을 방지하며, 비타민 C의 첨가는 항 산화제의 순수한 항산화력과 성분 간의 상승효과를 측정하는 데 중요한 요인이 되기도 한다[15]. Kadirvel 등(2005)은 세포 고사를 유발하는 비소를 처리한 후 비타민 C를 처리한 결과 caspase-3와 TNF- $a$ DNA 분절이 감소되는 것을 보고하였다 [18]. 또한 비타민 C가 첨가된 유자 추출물이 항산화 효과와 암세포 억제 활성을 나타낸다는 결과를 보고하였다[35].

라이코펜은 베타-카로틴, 루테인과 함께 붉은 색의 카로티 노이드계 색소 중 하나이다. 라이코펜은 유방암 세포와 자궁 내막암 세포에서 cyclin D와 cyclin-dependent kinases 2 (cdk2) 활성을 감소시킴으로써 세포 생존과 세포주기 진행에 영향을 주는 것으로 보고되었다[25]. 또한 세포 배지에 존재하 는 phytoene과 phytofluene 역시 라이코펜과 강한 상승작용 을 나타내며 유전자 발현에 관여하는 라이코펜의 직접, 간접 적인 작용에 대해서는 세포들 사이의 간극연접의 형성에 있어 주요한 역할을 하는 단백질인 connexin 43 의 발현과 전사를 촉진하는 것으로 보고되었다. 라이코펜은 구강종양세포에서 세포 간 연락을 증가시켜 세포 증식을 감소시키며 이러한 연 구들은 라이코펜 혹은 라이코펜의 산화물질이 직접적으로 혹 은 산화 의존성 세포들의 신호전달을 통하여 항산화 효과를 나타나는 것을 시사한다[27].

베타-카로틴은 비타민 $\mathrm{A}$ 전구체로 녹황색 채소나 과일에
함유된 카르티노이드이다. 면역기능 증강효과가 있고, 강력한 항산화제로서 인체 내 유해한 활성산소를 제거함으로써 노화 예방은 물론 항암효과도 있는 것으로 알려져 있다[6]. 또한 망 막의 기능이나 많은 조직의 상피세포의 분화와 증식을 정상적 으로 유지시키고 비타민 $\mathrm{A}$ 의 결핍에서 오는 제반 증상에 예방 효과가 있다고 알려져 있다. 베타-카로틴은 레티노이드와 마 찬가지로 항산화제로 작용하여 조직의 산화를 예방할 수 있으 며 상피세포를 재생시키는 작용이 있는 것으로 알려지고 있다 [31].

현재까지는 파프리카 및 그 성분들이 UVB에 의해 유도되 는 p53 경로 유전자들의 발현에 대한연구는 수행되지 않았다. 본 연구는 파프리카 및 그 성분인 비타민 $\mathrm{C}$, 라이코펜과 베타카로틴를 UVB를 조사한 $\mathrm{HaCaT}$ 세포에 처리하여 세포사멸과 p53 및 GADD45 유전자 발현에 미치는 영향을 규명하고자 하였다.

\section{재료 및 방법}

\section{추출물}

본 실험에서 사용된 파프리카 추출물은 $\mathrm{Yu}$ 등(2006) 논문에 보고된 방법을 참고하여 추출하였다. $80 \%$ methanol과 혼합하 여 24시간 동안 추출하고, 이를 총 3 번 반복 추출하였다. 추출 액은 여과지를 사용하여 3회 여과하고 회전감압 농축기로 농 축하여 동결건조를 한 후에 분말화하여 사용하였다[37].

\section{세포배양}

인간 각질형성 세포주인 $\mathrm{HaCaT}$ 세포는 $10 \%$ fetal bovine serum (FBS)와 $2 \mathrm{mM}$ L-glutamine이 함유되어 있는 RPMI-1640 (Gibco, USA)에서 $37^{\circ} \mathrm{C}, 5 \% \mathrm{CO}_{2}$ 배양기(Sanyo, Japan)에서 24시간 동안 배양하였다.

\section{UVB 조사 및 성분 처리}

$\mathrm{HaCaT}$ 세포를 $\mathrm{PBS}$ 로 세척시킨 후 UVB $(280-320 \mathrm{~mm}) 200$ $\mathrm{J} / \mathrm{m}^{2}$ 를 조사하고 정상배지 또는 파프리카 추출물, 비타민C (L-Ascorbic acid; USB, USA), 라이코펜(Sigma, USA)과 베타카로틴(Sigma)이 농도별로 함유된 배지를 처리하여 적정시간 동안 배양하였다.

\section{세포 생존율 분석}

세포 생존율 실험은 3-[4,5-dimethylthiazol-2-yl]-2,5-diphenyl tetrazolium bromide (MTT)를 이용하여 측정하였다. $\mathrm{HaCaT}$ 세포는 96 well multiplate (Nunc, USA)에 각 well 당 $1 \times 10^{5}$ 개의 세포를 분주하고, 24 시간 동안 배양한 후 $\mathrm{FBS}$ 가 첨 가된 새 배지로 교환하고 실험에 사용될 파프리카 추출물, 비 타민 C, 라이코펜과 베타-카로틴을 다양한 농도에서 24시간 처리하였다. 배양 후 phosphate buffered saline (PBS)로 세척 
한 후 $0.5 \mathrm{mg} / \mathrm{ml}$ 의 MTT (Sigma) 용액 $100 \mu 1$ 를 넣고, 4 시간 동안 $37^{\circ} \mathrm{C}$ 에서 배양한 후, $570 \mathrm{~nm}$ 에서 흡광도(ELISA reader, ReTiSoft, Canada)로 측정하여 그 효과를 정상 대조군에 대한 백분율로 산출하여 비교하였다.

\section{세포 고사에 의한 핵분절 분석}

자외선 혹은 파프리카 추출물, 비타민 C, 라이코펜과 베타카로틴에 의한 핵의 형태 변화를 관찰하고자 DAPI 염색을 수행하였다. $200 \mathrm{~J} / \mathrm{m}^{2} \mathrm{UVB}$ 를 조사하고 파프리카 추출물, 비 타민 C, 라이코펜이나 베타-카로틴을 농도별로 처리한 후 24 시간 동안 배양한 세포를 수거하여 $200 \mu \mathrm{ll}$ 의 PBS로 희석시켰 다. 희석시킨 세포 $15 \mu \mathrm{l}$ 에 DAPI $2 \mu \mathrm{l}$ 를 섞은 후 형광현미경 (Zeiss vision) X400 배율로 관찰하였다. 결과는 핵이 분절된 세포/전체 세포의 백분율로 계산하여 비교하였다.

\section{Western blot}

Lowery 방법에 따라 세포에 Lysis 용액을 넣은 후 얼음에서 20 분간 처리하고 원심분리 $\left(12,000 \mathrm{rpm}, 5\right.$ 분, $\left.4^{\circ} \mathrm{C}\right)$ 하여 단백질 이 함유된 상층액만을 회수하였다. 정제한 단백질은 Bradford 법으로 정량하였다. 정량한 단백질은 $12 \%$ SDS-polyacrylamide gel에서 분리시킨 후 Eletroblot system (Bio Rad) 을 사용하여 $250 \mathrm{~mA}$ 로 1시간 동안 polyvinylidene fluoride membrane에 옮겼다. TBS-T 완충용액으로 세척하고 $5 \% \mathrm{skim}$ milk에 놓아두었다. 각각의 항체가 들어있는 항혈청을 blocking 용액에 1:1,000으로 희석하여 처리하고 상온에서 흔들어 준 다음 TBS-T 완충용액으로 15 분간 3 번 세척하였다. Secondary antibody를 blocking 용액에 1:1,000으로 희석한 용 액을 처리한 후 TBST로 세척하였다. 암실에서 developing solution $\mathrm{A}$ 와 $\mathrm{B}$ 를 1:1로 혼합한 액을 처리한 후 곧 바로 Hyper film을 얹어 10 초에서 5 분 동안 노출한 후 현상하였다.

\section{결과 및 고찰}

세포 생존율은 3-[4,5-dimethylthiazol-2-yl]-2,5-diphenyl tetrazolium bromide (MTT) 방법으로 분석하였다. 파프리카 추출물만 처리한 경우 세포 생존율은 처리하지 않은 대조군과 통계적으로 유의미한 차이를 나타내지 않았으나 비타민 C의 경우 10 20 mM에서 약 $60 \%$ 정도 증가시키는 것을 관찰하였 다(Fig. 1A and B, open circles). 그러나 라이코펜과 베타-카로 틴의 경우 상대적인 고농도에서 약 20 25\% 정도 감소시키는 것으로 관찰되었다(Fig. 1C and D, open circles). 배양세포에 $\mathrm{UVB} 200 \mathrm{~J} / \mathrm{m}^{2}$ 을 조사한 후 24 시간 동안 다양한 농도의 파프 리카 추출물 또는 성분을 처리하여 세포 유전독성에 대한 추 출물의 효과를 분석하였다. UVB $\left(200 \mathrm{~J} / \mathrm{m}^{2}\right)$ 에 의해 정상 대조 군보다 약 $40 \%$ 감소된 세포 생존율은 파프리카 추출이나 비타 민 C의 후처리에 의해 각각 $10 \%$ 와 $35 \%$ 의 회복을 보였다(Fig.
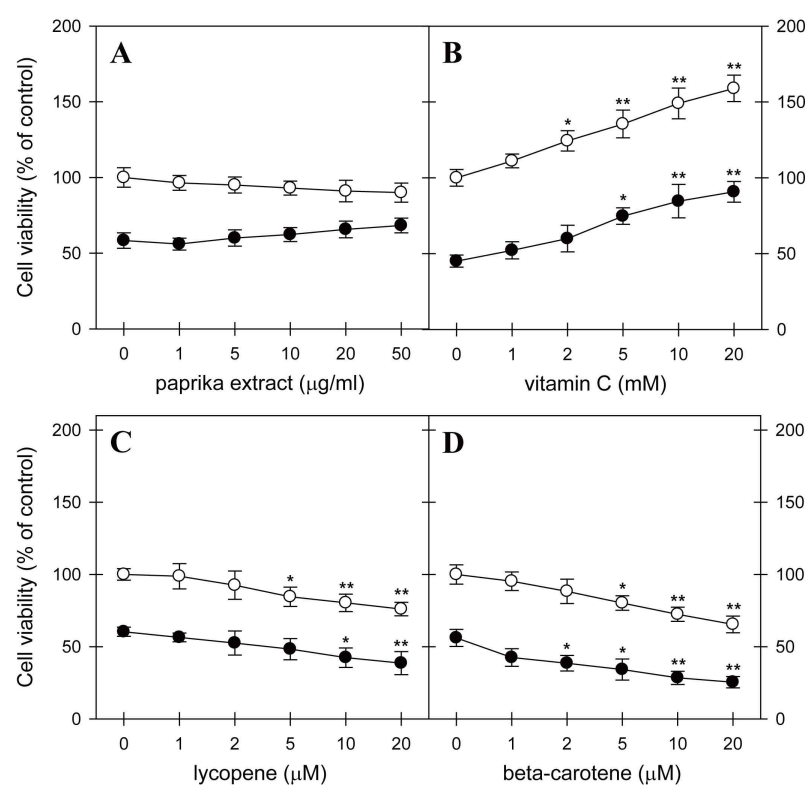

Fig. 1. Effect of paprika extract, vitamin C, lycopene or beta-carotene on the viability of $\mathrm{HaCaT}$ cells exposed to UVB as determined by MTT assay. Cells exposed to $200 \mathrm{~J} / \mathrm{m}^{2}$ UVB light (closed circles) or non-irradiated (open circles) were post-incubated for $24 \mathrm{hr}$ in normal growth medium or medium containing various concentrations of paprika extract $(\mathrm{A})$, vitamin $\mathrm{C}(\mathrm{B})$, lycopene $(\mathrm{C})$ and beta-carotene (D). Each data point represents the mean \pm SD of triplicate experiments. ${ }^{*}, p<0.05$ and ${ }^{*}, p<0.01$, respectively, versus normal medium post-incubation.

1A and B, closed circles). 그러나 UVB 조사 후 라이코펜이나 베타-카로틴을 후 처리하면 이러한 회복 효과를 보이지 않고, 오히려 각각 $20,30 \%$ 정도의 세포 생존율의 추가적인 감소를 보였다(Fig. 1C and D, closed circles). 비타민 C가 세포 생존율 및 증식을 증가시키는 것은 항산화 효과로 해석되어왔으며 [34], 라이코펜의 세포 생존율 감소 효과 중 하나는 connexin 43 수준의 증가로 해석된 바 있으나[27], 본 연구에서 규명된 베타-카로틴의 세포 생존율 감소 현상이 $\mathrm{HaCaT}$ 세포에서만 특이하게 나타난 것인지는 추후의 연구에서 규명하고자 한다.

자외선에 의한 세포고사에서 파프리카 추출물, 비타민 C, 라이코펜과 베타-카로틴의 효과를 알아보기 위해 세포고사 때 나타나는 핵 분절화 현상을 DAPI 염색을 통해 분석하고 그 결과를 세포고사율로 제시하였다(Fig. 2). 파프리카 추출물이 나 비타민 $C$ 만 처리했을 경우 처리하지 않은 대조군과 큰 차이 를 나타내지 않았다(Fig. 2A and B, open circles). 그러나 UVB 를 조사한 후 파프리카 추출물이나 비타민 $\mathrm{C}$ 를 처리한 경우 정상배지 처리군에 비해 농도 의존적으로 세포고사율이 각각 $24,42 \%$ 정도까지 감소하는 것을 확인할 수 있었다(Fig. $2 \mathrm{~A}$ and B, closed circles). 라이코펜과 베타-카로틴만 처리했을 경 우 농도 의존적으로 처리하지 않은 대조군에 비해 세포고사율 이 점차 증가하였다(Fig. $2 \mathrm{C}$ and D, open circles). UVB를 조사 

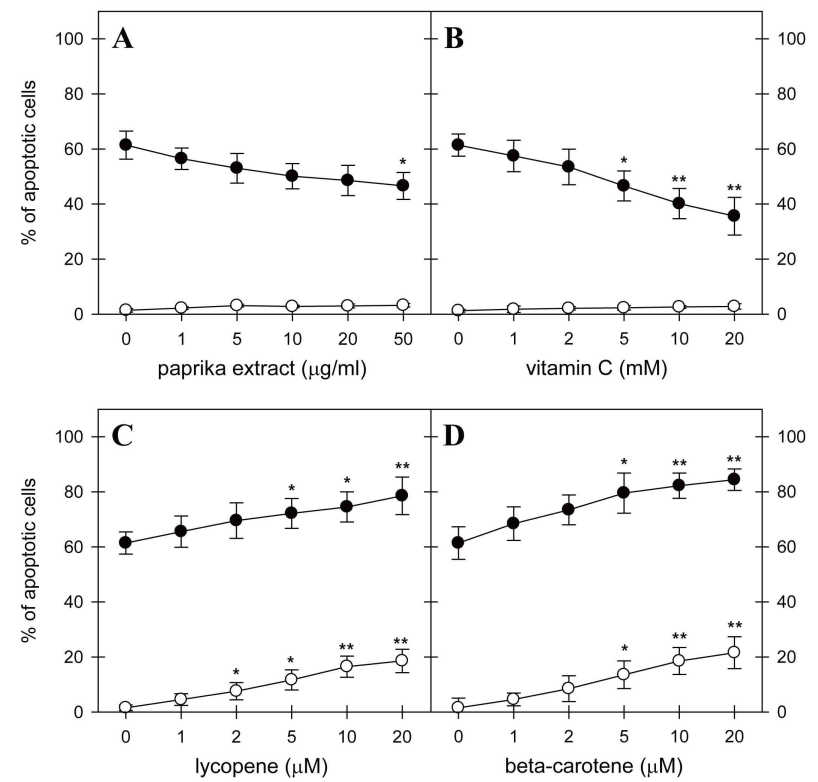

Fig. 2. Protecive effect of paprika extract, vitamin $\mathrm{C}$, lycopene or beta-carotene on the UVB-induced nuclear fragmentation as determined by DAPI staining. Apoptotic index of cells exposed to UVB (closed circles) or not (open circles) and post-incubated for $24 \mathrm{hr}$ in growth medium containing various concentration of paprika extract (a), vitamin C (b), lycopene (c) or beta-carotene (d), as determined by DAPI staining. Each data point represents the mean \pm SD of triplicate experiments. *, $p<0.05$ and **, $p<0.01$, respectively, versus normal medium post-i ncubation.

한 후 라이코펜과 베타-카로틴을 처리한 경우에도 상대적인 고농도에서 세포고사율이 각각 $30,40 \%$ 정도 증가하는 것을 확인할 수 있었다(Fig. 2C and D, closed circles). 이와 같은 결과 는 자외선을 조사한 후 파프리카 추출물과 비타민 $\mathrm{C}$ 를 처리한 경우 파프리카 추출물과 비타민 $\mathrm{C}$ 의 보호효과에 의하여 세포 고사를 일으키는 세포가 현저히 줄어드는 현상을 나타냈다. 이 결과는 세포 생존율(Fig. $1 \mathrm{~A}$ and B)과 거의 일치하는 것으 로 보아 파프리카 추출물과 비타민 $\mathrm{C}$ 가 자외선에 의한 세포고 사를 보호하는 효과를 지닌 것으로 생각된다. 그러나 라이코 펜과 베타-카로틴을 처리하면 라이코펜과 베타-카로틴이 가진 세포독성에 의해 세포고사가 더욱 증가하는 것을 확인할 수 있었다. 이 결과들은 또한 apoptosis의 다른 분석법인 internucleosomal DNA ladder 양상에서도 정상적으로 확인되었 다(data not shown).

세포 상해에 미치는 영향을 분자적으로 확인하기 위해 $\mathrm{p} 53$ 과 GADD45의 단백질 수준을 Western blot으로 분석하였다 (Figs. 3-6). 파프리카 추출물만 처리했을 경우 p53과 GADD45 단백질발현량은 처리하지 않은 대조군과 비교해서 큰 차이를 나타내지 않았다(Fig. 3A and B, open circles). 그러나 UVB를 조사한 후 파프리카 추출물을 처리한 경우 정상배지 처리군에

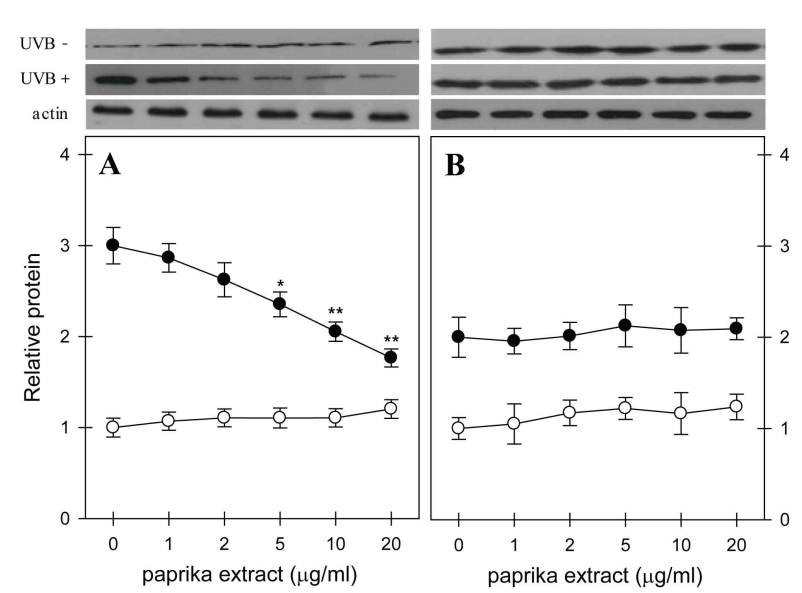

Fig. 3. Effect of post-incubation for $24 \mathrm{hr}$ with various concentrations of paprika extract on the levels of p53 and GADD45 protein in non-irradiated (open circles) or 200 $\mathrm{J} / \mathrm{m}^{2}$ UVB-exposed (closed circles) HaCaT cells. Representative Western blot products p53 (A) and GADD45 (B) protein levels as compared with beta actin protein levels determined by densitometric measurements of the bands in (A, B) and normalized to those in nontreated control. Each data point represents the mean \pm SD of triplicate experiments. *, $p<0.05$ and **, $p<0.01$, respectively, versus normal medium postincubation.

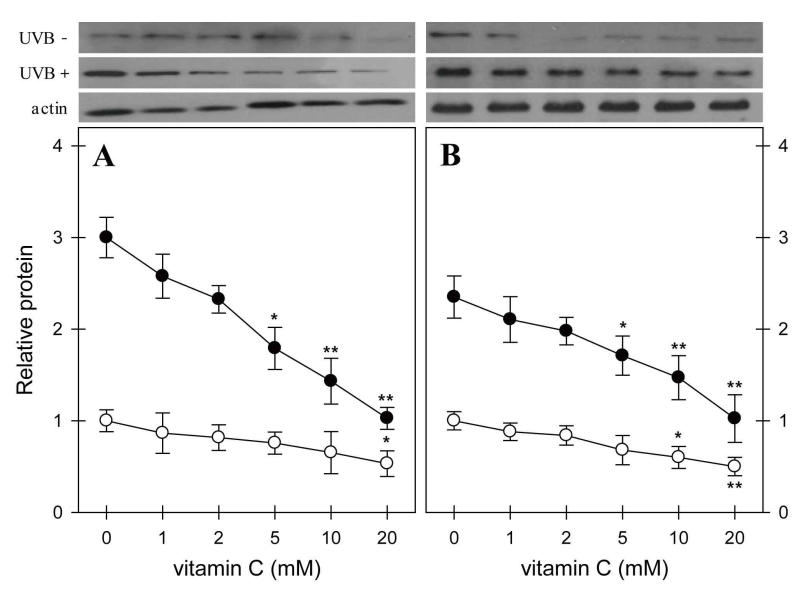

Fig. 4. Effect of post-incubation for $24 \mathrm{hr}$ with various concentrations of vitamin $C$ on the levels of p53 and GADD45 protein in not (open circles) or $200 \mathrm{~J} / \mathrm{m}^{2}$ UVB-exposed (closed circles) HaCaT cells. Representative Western blot products p53 (A) and GADD45 (B) protein levels as compared with beta actin protein levels determined by densitometric measurements of the bands in (A, B) and normalized to those in nontreated control. Each data point represents the mean $\pm \mathrm{SD}$ of triplicate experiments. *, $p<0.05$ and ${ }^{* *}, p<0.01$, respectively, versus normal medium post-incubation.

비해 농도 의존적으로 $\mathrm{p} 53$ 단백질 발현량이 약 $40 \%$ 정도까지 감소하였으나 특이하게도 GADD45 단백질 발현량의 경우 유 
의적인 차이를 나타내지 않았다(Fig. $3 \mathrm{~A}$ and B, closed circles). 비타민 $\mathrm{C}$ 만 처리했을 경우에는 p53과 GADD45 단백질의 발 현량은 상대적인 고농도에서 각각 약 $50 \%$ 정도까지 감소하는 것을 확인할 수 있었다(Fig. $4 \mathrm{~A}$ and B, open circles). UVB를 조사한 후 비타민 $\mathrm{C}$ 를 처리했을 경우에는 p53과 GADD45 단 백질 발현량이 각각 $70,56 \%$ 정도 큰 폭으로 감소하였다(Fig. $4 \mathrm{~A}$ and $\mathrm{B}$, closed circles).

직전에 언급한 파프리카 추출물이나 비타민 $\mathrm{C}$ 의 긍정적인 효과와는 대조적으로, 라이코펜이나 베타-카로틴을 각각 단독 처리시 p53과 GADD45 단백질 발현량은 처리하지 않은 대조 군에 비해 농도 의존적으로 증가하였다(Figs. 5 and 6, open circles). UVB를 조사한 후 베타-카로틴을 처리한 경우에도 상 대적인 고농도에서 p53과 GADD45 단백질 발현량이 약 2배 정도 증가하는 것을 확인할 수 있었다(Figs. 5 and 6, closed circles). 파프리카 추출물, 비타민 C, 라이코펜, 그리고 베타-카 로틴의 p53 및 GADD45에 대한 단백질 수준의 결과들은 전사 체 수준에서도 유사함이 RT-PCR에 의해 확인되었으며, p53 단백질의 수준변화는 인산화된 p53 단백질의 수준변화와 유 사하였다(data not shown).

p53 유전자는 DNA에 결합하여 세포 주기 중 G1-S phase check point로 손상 DNA를 복구하거나, 손상 DNA를 고사 시켜 세포 증식을 억제하는 암 억제 유전자로 알려져 있다[26]. DNA 상해 요인을 세포에 처리했을 경우 p53 단백질은 세포 주기 점검 상에서 현저한 조절 작용을 수행하게 되는데 예를

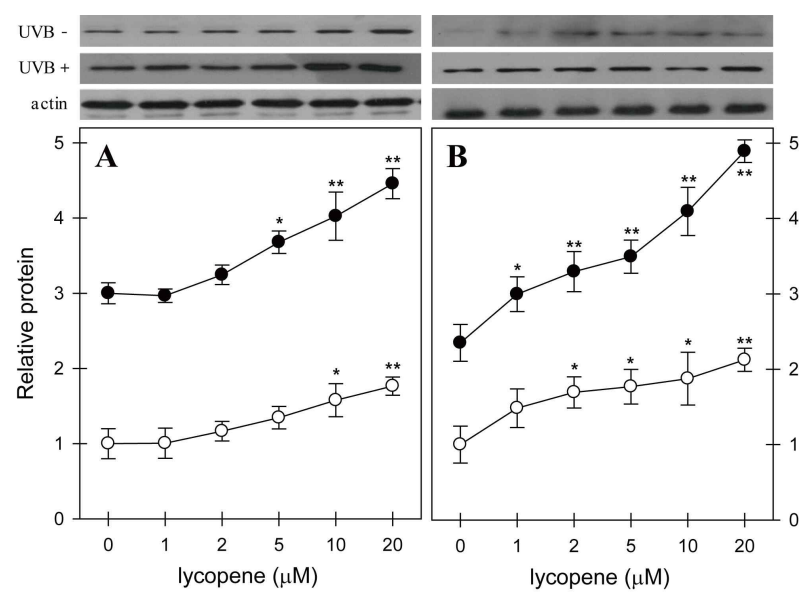

Fig. 5. Effect of post-incubation for $24 \mathrm{hr}$ with various concentrations of lycopene on the levels of p53 and GADD45 protein in not (open circles) or $200 \mathrm{~J} / \mathrm{m}^{2}$ UVB-exposed (closed circles) HaCaT cells. Representative Western blot products p53 (A) and GADD45 (B) protein levels as compared with beta actin protein levels determined by densitometric measurements of the bands in $(\mathrm{A}, \mathrm{B})$ and normalized to those in nontreated control. Each data point represents the mean $\pm \mathrm{SD}$ of triplicate experiments. *, $p<0.05$ and $* *, p<0.01$, respectively, versus normal medium post-incubation.

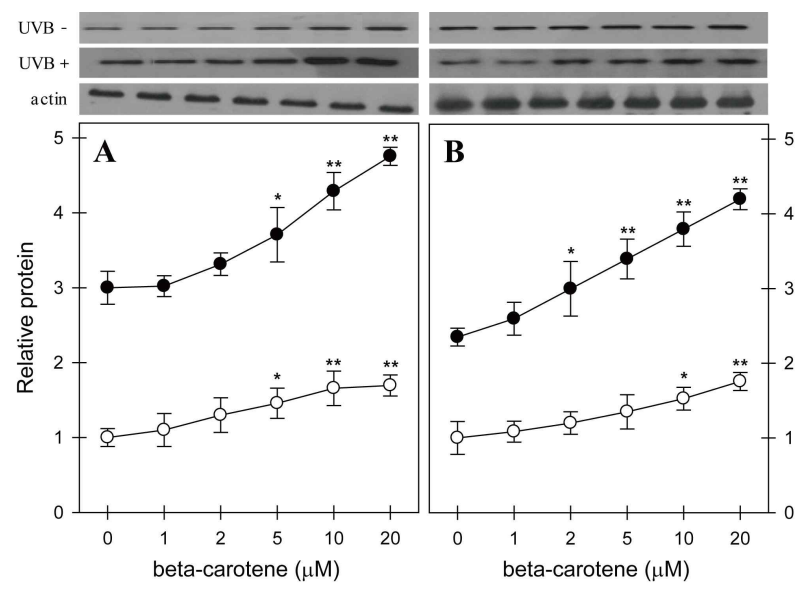

Fig. 6. Effect of post-incubation for $24 \mathrm{hr}$ with various concentrations of beta-carotene on the levels of p53 and GADD45 Western blot in not (open circles) or $200 \mathrm{~J} / \mathrm{m}^{2}$ UVB-exposed (closed circles) HaCaT cells. Representative Western blot products p53 (A) and GADD45 (B) protein levels as compared with beta actin protein levels determined by densitometric measurements of the bands in $(\mathrm{A}, \mathrm{B})$ and normalized to those in nontreated control. Each data point represents the mean \pm SD of triplicate experiments. ${ }^{*}, p<0.05$ and ${ }^{* *}, p<0.01$, respectively, versus normal medium post-incubation.

들어 $\mathrm{DNA}$ 단사 절단이 일어나면 $\mathrm{p} 53$ 의존성 신호 전달이 개시되어 세포 내 p53의 수준이 향상된다. p53의 역할은 세포 고사뿐만 아니라 p53은 GADD45를 통해 DNA 회복과 연관됨 이 보고되었다. 비타민 C는 산화적 스트레스에 대해 보호하는 효능이 있다고 알려져왔다[2,15,29]. 자외선 스트레스에 의해 발현된 p53 단백질 발현 증가가 파프리카 추출물이나 비타민 $\mathrm{C}$ 를 후 처리한 결과 점차 감소(Figs. 3-4A and B, closed circles), 핵 분절율 감소(Fig. 2A and B, closed circles), 세포 생존율 증가 (Fig. 1A and B, closed circles) 되는 것으로 보아 파프리카 추출 물과 비타민 $\mathrm{C}$ 이 자외선에 의한 세포고사를 보호하는 효능이 있다고 생각된다. 또한 정상배지와 파프리카 추출물의 p53 $\mathrm{mRNA}$ 발현량의 감소 시간이 12 시간 점차 감소되는 반면에 비타민 C는 9시간부터 감소되는 것으로 보아 비타민 C가 정상 배지나 파프리카 추출물보다 세포고사를 보호하는 효능이 더 빠르게 나타나는 것을 알 수가 있었다(data not shown).

라이코펜과 베타-카로틴의 경우에는 UVB라는 유전적 스트 레스에 의해 발현된 p53 단백질 발현량이 농도 의존적으로 (Figs. 5-6A and B, closed circles), 그리고 시간 의존적으로(data not shown) 점차 증가하는 것으로 보아 UVB에 의한 세포고사 가 라이코펜과 베타-카로틴에 의해 증가되는 것으로 생각된 다. 라이코펜의 세포 활성의 감소는 connexin 43 의 발현과 전 사를 촉진시켜 세포간의 증식을 감소시킨다고 이미 보고되었 다[27]. 그러나 라이코펜이 p53 단백질의 발현도 증가시키는 것으로 보아 간극연접뿐만 아니라 세포주기의 정지와 세포고 
사에도 직접, 간접적인 영향을 주는 것으로 생각된다.

본 연구 결과에 기초하여 후속 연구에는 비타민 C, 라이코 펜, 베타-카로틴의 성분이 직접, 간접적으로 미치는 p53 경로 유전자들에 대해 확대하여 분석하고자 한다.

\section{감사의 글}

이 논문은 2009학년도 원광대학교의 교비 지원에 의해 수행 됨.

\section{References}

1. Ambach, W. and M. Blumthaler. 1993. Biological effectiveness of solar UV radiation in humans. Experientia 49, 747-753.

2. Baumeister, P., T. Huebner, M. Reiter, S. Schwenk-Zieger, and U. Harréus. 2009. Reduction of oxidative DNA fragmentation by ascorbic acid, zinc and $\mathrm{N}$-acetylcysteine in nasal mucosa tissue cultures. Anticancer Res. 29, 4571-4574.

3. Bevan, R. J., N. Mistry, P. R. Patel, E. P. Halligan, R. Dove, and J. Lunec. 2010. Can vitamin C induce nucleotide excision repair? Support from in vitro evidence. Br. J. Nutr. 103, 686-695.

4. Biacs, P. A., H. G. Daood, T. T. Huszka, and P. K. Biacs. 1993. Carotenoids and carotenoid esters from new cross cultivars of paprika. J. Agric. Food Chem 41, 1864-1867.

5. Bononi, M., F. Gallone, and F. Tateo. 2010. Validation data for HPLC/FLD determinations of ochratoxin A in red paprika and black pepper adopting a one-step clean-up procedure. Food Addit. Contam Part A Chem Anal. Control Expo. Risk Assess 27, 249-254.

6. Burri, B. J. 1997. Beta-carotene and human health: a review of current research. Nutr. Res. 17, 547-580.

7. Carlisle, D. L., D. E. Pritchard, J. Singh, B. M. Owens, L. J. Blankenship, J. M. Orenstein, and S. R. Patierno. 2000. Apoptosis and p53 induction in human lung fibroblasts exposed to chromium (VI): effect of ascorbate and tocopherol. Toxicol. Sci. 55, 60-68.

8. Choi, W. J., S. H. Youn, J. H. Back, S. Park, E. J. Park, K. J. Kim, H. R. Park, A. L. Kim, and K. H. Kim. 2011. The role of KLF4 in UVB-induced murine skin tumor development and its correlation with cyclin D1, p53, and p21(Waf1/Cip1) in epithelial tumors of the human skin. Arch Dermatol Res. 303, 191-200.

9. Fisher, C. and J. A. Kocis. 1987. Separation of paprika pigment by HPLC. J. Agric. Food Chem 35, 55-57.

10. F'guyer, S., F. Afaq, and H. Mukhtar. 2003. Photochemoprevention of skin cancer by botanical agents. Photodermatol. Photoimmunol. Photomed 19, 56-72.

11. Gambichler, T., C. Tigges, A. Dith, M. Skrygan, N. Scola, P. Altmeyer, and A. Kreuter. 2011. Impact of etanercept treatment on ultraviolet B-induced inflammation, cell cycle regulation and DNA damage. Br. J. Dermatol. 164, 110-115.
12. Granstein, R. D. and M. S. Matsui. 2004. UV radiation-induced immunosuppression and skin cancer. Cutis. 74, 4-9.

13. Hahm, E., D. H. Jin, J. S. Kang, Y. I. Kim, S. W. Hong, S. K. Lee, H. N. Kim, D. J. Jung, J. E. Kim, D. H. Shin, Y. I. Hwang, Y. S. Kim D. Y. Hur, Y. Yang, D. Cho, M. S. Lee, and W. J. Lee. 2007. The molecular mechanisms of vitamin $\mathrm{C}$ on cell cycle regulation in B16F10 murine melanoma. J. Cell Biochem 102, 1002-1010.

14. Ha, S. E., D. H. Shin, H. D. Kim, S. M. Shim, H. S. Kim, B. H. Kim, J. S. Lee, and J. K. Park. 2010. Effects of ginsenoside $\mathrm{Rg} 2$ on the ultraviolet B-induced DNA damage responses in HaCaT cells. Naunyn Schmiedebergs Arch Pharmacol. 382, 89-101.

15. Heck, D. E., D. R. Gerecke, A. M. Vetrano, and J. D. Laskin. 2004. Solar ultraviolet radiation as a trigger of cell signal transduction. Toxicol. Appl. Pharmacol. 195, 288-297.

16. Ittah, Y., J. Kanner, and R. Granity. 1993. Hydrolysis study of carotenoid pirment paprika by HPLC/photodiode array detection. J. Agric. Food Chem 41, 899-901.

17. Kaack, K. and T. Austed. 1998. Interaction of vitamin C and flavonoids in elderberry (Sambucus nigra $L$ ) during juice procession. Plant Foods Human Nutr. 52, 187-119.

18. Kadirvel, R., A. Muthuswany, S. Dmuel, and P. Chinnakannu. 2005. Ascorboic acid and a-tocopherol as potent modulators of apoptosis on arsenic toxicity in rats. Toxicol. Lett. 156, 297-306.

19. Kang, E. S., K. Iwata, K. Ikami, S. A. Ham, H. J. Kim, K. C. Chang, J. H. Lee, J. H. Kim, S. B. Park, J. H. Kim, C. Yabe-Nishimura, and H. G. Seo. 2011. Aldose reductase in keratinocytes attenuates cellular apoptosis and senescence induced by UV radiation. Free Radic. Biol. Med 50, 680-688.

20. Kim, J. E., D. H. Jin, S. D. Lee, S. W. Hong, J. S. Shin, S. K. Lee, D. J. Jung, J. S. Kang, and W. J. Lee. 2008. Vitamin $\mathrm{C}$ inhibits p53-induced replicative senescence through suppression of ROS production and 38 MAPK activity. Int. J. Mol. Med. 22, 651-655.

21. Knowles, L. M., D. A. Zigrossi, R. A. Tauber, C. Hightower, and J. A. Milner. 2000. Flavonoids suppress androgen-independent human prostate tumor proliferation. Nutr. Cancer 38, 116-122.

22. Matsumura, Y. and H. N. Ananthaswamy. 2004. Toxic effects of ultraviolet radiation on the skin. Toxicol. Appl. Pharmacol. 195, 298-308.

23. Millau, J. F., O. J. Bandele, J. Perron, N. Bastien, E. F. Bouchard, L. Gaudreau, D. A. Bell, and R. Drouin. 2010. Formation of stress-specific p53 binding patterns is influenced by chromatin but not by modulation of p53 binding affinity to response elements. Nucleic Acids Res. 39, 3053-3063.

24. Liu, C., X. D. Wang, L. Mucci, J. M. Gaziano, and S. M. Zhang. 2009. Modulation of lung molecular biomarkers by beta-carotene in the physicians' health study. Cancer 115, 1049-58.

25. Nahum, A., K. Hirsch, M. Danilenko, C. K. W. Watts, O. W. J. Prall, J. Levy, and Y. Sharoni. 2001. Lycopene inhibition of cell cycle progression in breast and endometrial 
cancer cells is associated with reduction in cyclin D levels and retention of p27Kip1 in the cyclin E cdk2 complexes. Oncogene 20, 3428-3436.

26. Liang, Y., S. Y. Lin, F. C. Brunicardi, J. Goss, and K. Li. 2008. DNA damage response pathways in tumor suppression and cancer treatment. World J. Surg. 33, 661-666.

27. Livny, O., I. Kaplan, R. Reifen, S. Polak-Charcon, Z. Mader, and B. Schwartz. 2002. Lycopene inhibits proliferation and enhances gap-junction communication of KB-1 human oral tumor cells. J. Nutr. 132, 3754-3759.

28. Palozza, P., R. Simone, A. Catalano, A. Boninsegna, V. Böhm, K. Fröhlich, M. C. Mele, G. Monego, and F. O. Ranelletti. 2010. Lycopene prevents 7-ketocholesterol-induced oxidative stress, cell cycle arrest and apoptosis in human macrophages. J. Nutr. Biochem 21, 34-46.

29. Palozza, P., S. Serini, S. Verdecchia, M. Ameruso, S. Trombino, N. Picci, G. Monego, and F. O. Ranelletti. 2007. Redox regulation of 7-ketocholesterol-induced apoptosis by beta-carotene in human macrophages. Free Radical Biol. Med 42, 1579-1590.

30. Palozza, P., A. Sheriff, S. Serini, A. Boninsegna, N. Maggiano, F. O. Ranelletti, G. Calviello, and A. Cittadini. 2005. Lycopene induces apoptosis in immortalized fibroblasts exposed to tobacco smoke condensate through arresting cell cycle and down-regulating cyclin D1, pAKT and pBad. Apoptosis 10, 1445-1456.

31. Palozza, P., S. Serini, F. Di Nicuolo, A. Boninsegna, A. Torsello, N. Maggiano, F. O. Wolf FI, G. Calviello, and A. Cittadini. 2004. Beta-carotene exacerbates DNA oxidative damage and modifies p53-related pathways of cell proliferation and apoptosis in cultured cells exposed to tobacco smoke condensate. Carcinogenesis 25, 1315-1325.

32. Plessinger, M. A., J. R. Woods, and R. K. Miller. 2000. Pretreatment of human amnion-chorion with vitamins $\mathrm{C}$ and $\mathrm{E}$ prevents hypochlorous acid-induced damage. Am J. Obstet. Gynecol. 183, 979-985.

33. Saeed, R. W., T. Peng, and C. N. Metz. 2003. Ascorbic acid blocks the growth inhibitory effect of tumor necrosis factor-alpha on endothelial cells. Exp. Biol. Med 228, 855-865.

34. Powley, I. R., A. Kondrashov, L. A. Young, H. C. Dobbyn, K. Hill, I. G. Cannell, M. Stoneley, Y. W. Kong, J. A. Cotes, G. C. Smith, R. Wek, C. Hayes, T. W. Gant, K. A. Spriggs, M. Bushell, and A. E. Willis. 2009. Translational reprogramming following UVB irradiation is mediated by DNA-PKcs and allows selective recruitment to the polysomes of mRNAs encoding DNA repair enzymes. Genes Dev. 23, 1207-1220.

35. Shon, M. Y. and S. K. Park. 2006. Synergistic effect of Yuza (Citrus junos) extracts and ascorbic acid on antiproliferation of human cancer cells and antioxidant activity. Korean J. Food Preserv. 13, 649-654.

36. Wu, F., K. Tyml, and J. X. Wilson. 2002. Ascorbate inhibits iNOS expression in endotoxin and IFN gamma-stimulated rat skeletal muscle endothelial cells. FEBS Lett. 520, 122-126.

37. Yu, M. H., H. J. Lee, H. G. Im, S. O. Lee, and I. S. Lee. 2006. Induction of quinone reductase activity in hepatoma cells by paprika (Capsicum annuum L.). Korean J. Food Sci. Technol. 35, 707-711. 


\section{초록 : UVB를 조사한 HaCaT 세포의 세포사멸과 p53 및 GADD45 유전자 발현에 대한 파프리카 추 출물 및 성분들의 효과}

하세은 · 김형도 · 강제란 · 박종군

(원광대학교 생명과학부)

본 연구는 파프리카 추출물과 그 성분인 비타민 C, 라이코펜과 베타-카로틴이 UVB (ultraviolet-B)에 의한 유 전독성의 감소에 효과를 보이는 지를 $\mathrm{HaCaT}$ 세포를 이용하여 분석하였다. 자외선을 조사하지 않은 정상 세포 의 세포활성은 파프리카 추출물을 경우 처리하지 않은 대조군과 차이를 나타내지 않았지만 비타민 C의 경우 농 도 의존적으로 증가시키는 것을 관찰하였다. 그러나 라이코펜과 베타-카로틴의 경우 농도 의존적으로 점차 세포 활성이 감소하는 것으로 관찰되었다. UVB로 상해받은 세포를 추출물이나 그 성분으로 후 배양할 경우 정상 배 양액으로 배양한 대조군에 비해 파프리카 추출물과 비타민 $C$ 은 농도 의존적으로 세포 활성을 증가시켰으나 라 이코펜과 베타-카로틴의 경우 농도 의존적으로 감소키는 것을 관찰할 수 있었다. 자외선을 조사하지 않은 정상 세포의 핵 분절율은 파프리카 추출물과 비타민 C의 경우 대조군과 유의적인 차이를 나타내지 않았지만, 라이코 펜, 베타-카로틴의 경우 농도 의존적으로 핵 분절율이 증가하는 것을 관찰하였다. UVB를 조사한 후 파프리카 추출물이나 비타민 $\mathrm{C}$ 를 처리한 경우 정상 배양액으로 배양한 대조군에 비해 핵 분절율을 감소시켰지만 라이코 펜과 베타-카로틴의 경우 농도 의존적으로 증가시켰다. 세포 상해에 반응하는 유전자인 p53과 GADD45의 단백 질 수준을 Western blot으로 분석한 결과, 파프리카 추출물만 처리했을 경우 p53과 GADD45 단백질 수준은 처 리하지 않은 대조군과 비교해서 유의미한 차이를 나타내지 않았으나 UVB를 조사한 후 파프리카 추출물을 처리 한 경우 농도 의존적으로 $\mathrm{p} 53$ 단백질 발현량이 감소하였다. 비타민 C를 단독 처리할 경우 대조군에 비해 p53과 $\mathrm{GADD} 45$ 단백질 발현량은 감소하였으며, $\mathrm{UVB}$ 를 조사한 후 비타민 C를 처리한 경우에도 농도 의존적으로 p53 과 GADD45 단백질 발현량이 감소하는 것을 확인할 수 있었다. 그러나 라이코펜과 베타-카로틴만 단독 처리할 경우 p53과 GADD45 단백질 발현량이 처리하지 않은 대조군에 비해 농도 의존적으로 증가하였다. UVB를 조사 한 후 베타-카로틴을 처리한 경우에도 상대적인 고농도에서 p53과 GADD45 단백질 발현량이 증가하는 것을 확 인할 수 있었다. 위의 결과를 토대로 파프리카 추출물과 비타민 C는 UVB에 의해 손상된 세포의 세포 독성을 회복하는 효능이 있다고 생각된다. 라이코펜과 베타-카로틴의 경우에는 UVB에 의해 발현된 p53 단백질의 수준 이 농도 의존적으로 더욱 증가하는 것으로 보아 UVB에 의한 세포고사가 라이코펜과 베타-카로틴에 의해 강화 되는 것으로 생각된다. 